\title{
A Novel Phage Genome Integrated into a Plasmid in Bacillus thuringiensis Strain AF101
}

\author{
By KOHZO KANDA*, YEPIN TAN† AND KEIO AIZAWA \\ Institute of Biological Control, Faculty of Agriculture, Kyushu University, Fukuoka 812, Japan
}

(Received 28 March 1989; revised 3 July 1989; accepted 7 July 1989)

Bacillus thuringiensis strain AF101 possesses a single plasmid (pAF101) with a molecular size of $42 \mathrm{MDa}(69 \mathrm{~kb})$. During plasmid curing experiments in strain AF101, we found that a phage $(\mathrm{J} 7 \mathrm{~W}-1)$ was induced by ethidium bromide treatment. Moreover, the phage genome $(48 \mathrm{~kb})$ hybridized only with pAF 101 on a Southern blot of the DNA of a cleared lysate prepared from strain AF101. Comparison of the restriction patterns of pAF101 and J7W-1 phage DNA revealed that pAF101 contains not only the entire phage DNA but also a plasmid-specific DNA region. These results indicate that the J7W-1 genome has been stably integrated into pAF101 in strain AF101. Integration of the J7W-1 genome into a plasmid was also observed after phage infection of the type strain of $B$. thuringiensis subsp. israelensis.

\section{INTRODUCTION}

Bacillus thuringiensis is well known for the production of parasporal inclusions (crystals) toxic to lepidopterous and dipterous insects, and it has become one of the most important nonchemical agents for the control of insect pests. The selection and breeding of effective strains of this bacterium is important to develop its utilization potential as a microbial insecticide (Aizawa, 1971). Among these effective strains, B. thuringiensis strain AF101 (H-serotype 4a :4b) has been selected as a strain with low toxicity to the silkworm, Bombyx mori, but highly toxic to the common cabbageworm, Pieris rapae crucivora, the fall webworm, Hyphantria cunea, and the diamondback moth, Plutella xylostella (Aizawa et al., 1975). This strain is suitable for use as an insecticide in sericultural countries, particularly in Asia.

Recently, molecular biological approaches have been adopted in order to improve strains of $B$. thuringiensis. These have particularly concentrated on the crystal gene, which has been revealed to be plasmid-located, by plasmid curing (González et al., 1981; Lereclus et al., 1982), plasmid transfer (González et al., 1983; Klier et al., 1983; Battisti et al., 1985), and gene cloning (summarized by Aronson et al., 1986). Various strains of $B$. thuringiensis harbour a large array of plasmids; however, the genetic information located on these plasmids is not known except for the presence of the crystal gene and possibly genes associated with phage-like particles (Tam \& Fitz-James, 1986).

In the present study, we investigated the biological function of a plasmid (pAF101) which is associated with crystal production in B. thuringiensis strain AF101 and describe the presence of a prophage in pAF101.

\section{METHODS}

Strains. Bacillus thuringiensis strain AF101 (H-serotype 4a :4b) reported by Aizawa et al. (1975) and type strains of $B$. thuringiensis used in this study were obtained from culture collections maintained in this institute.

Media. BHI broth contained $37 \mathrm{~g}$ brain-heart infusion (Difco) $\mathrm{l}^{-1}(\mathrm{pH} 7 \cdot 2)$. LB broth was prepared as described by Maniatis et al. (1982). For solid medium, $15 \mathrm{~g}$ agar (Difco) $\mathrm{I}^{-1}$ was added to LB broth. Soft agar for the assay of phage consisted of LB broth containing $0 \cdot 7 \%$ agar.

$\dagger$ Present address: Department of Virology and Molecular Biology, Wuhan University, Wuhan, China. 
Extraction and purification of plasmid. The extraction of the plasmid from B. thuringiensis strain AF101 was done according to the method of Battisti et al. (1985), except that proteinase K (Merck) was used instead of lysozyme. Plasmid in cleared lysate was purified by $\mathrm{CsCl} /$ ethidium bromide centrifugation (Maniatis et al., 1982). The electrophoresis of DNA was done on a $0.7 \%$ agarose gel in TAE buffer (0.04 M-Tris/acetate, $2 \mathrm{mM-EDTA,pH} \mathrm{8.0)}$ at $50 \mathrm{~V}$ for $120 \mathrm{~min}$ at room temperature.

Induction of phage. A cell suspension cultivated at $27^{\circ} \mathrm{C}$ for $16 \mathrm{~h}$ in LB broth was inoculated $(1: 100)$ into fresh LB broth containing 0.5-5 $\mu$-ethidium bromide, and cultured at $27^{\circ} \mathrm{C}$ with continuous shaking. Cell growth was examined by measuring the optical density $(660 \mathrm{~nm})$ of the cell culture at $1 \mathrm{~h}$ intervals. The phage suspension was prepared from the cell lysate by centrifugation at $20000 \mathrm{~g}$ for $1 \mathrm{~h}$ at $4{ }^{\circ} \mathrm{C}$, after removing cell debris by centrifugation at $10000 \mathrm{~g}$ for $20 \mathrm{~min}$ at $4{ }^{\circ} \mathrm{C}$. Phage particles were purified by $10-40 \%$ sucrose density-gradient centrifugation using a Spinco SW25-1 rotor at 23000 r.p.m. for $1 \mathrm{~h}$ at $4{ }^{\circ} \mathrm{C}$. Phage DNA was extracted by phenol treatment after incubation of the phage particles with $0.2 \%$ SDS at $37^{\circ} \mathrm{C}$ for $30 \mathrm{~min}$.

Phage infection. The infectivity of the phage was examined by a spot test. Cells were cultivated in LB broth at $27{ }^{\circ} \mathrm{C}$ until the mid-exponential phase and inoculated into a top layer of $3 \mathrm{ml} \mathrm{0.7 \%} \mathrm{soft} \mathrm{LB}$ agar on an LB agar plate. Samples $(50 \mu \mathrm{l})$ of phage suspension (approximately $7 \times 10^{6}$ p.f.u. $\mathrm{ml}^{-1}$ ) were spotted on the surface and the lytic response of cells to the phage was scored after incubation of the plate at $27^{\circ} \mathrm{C}$ for $24 \mathrm{~h}$.

Southern blotting and hybridization. Plasmid and chromosomal DNAs in cleared lysates were separated on $0.7 \%$ agarose gels and transferred to nitrocellulose membrane (Sartorius) by the Southern blotting technique (Maniatis et al., 1982). Peroxidase-labelled HindIII fragments of phage J7W-1 DNA were used as a hybridization probe. The enzyme-labelled DNA was prepared by using the Labezyme-POD set (Wako Pure Chemical Industries) and DNA-DNA hybridization was done according to the procedure recommended by the supplier.

Restriction enzyme analysis of plasmid and phage DNA. Plasmid and phage DNAs purified by $\mathrm{CsCl} / \mathrm{ethidium}$ bromide centrifugation were digested with restriction endonucleases (Nippon Gene). The reaction conditions were as recommended by the supplier. Digests were analysed by $0.7 \%$ agarose gel electrophoresis.

\section{RESULTS}

\section{Plasmid content of strain AF101}

The cleared lysate was examined to detect a plasmid array in strain AF101 by agarose gel electrophoresis. This strain harboured only one type of plasmid, which we termed pAF101. The size of pAF101 was estimated to be $42 \mathrm{MDa}(69 \mathrm{~kb})$ by comparison with plasmids whose sizes were already known in the type strain of B. thuringiensis subsp. thuringiensis (González \& Carlton, 1980).

To investigate the biological function of this plasmid, curing of pAF101 from strain AF101 was attempted by treatment with SDS and ethidium bromide. After cultivation of cells for $8 \mathrm{~h}$ at $27^{\circ} \mathrm{C}$ in LB broth containing $0.002 \%$ SDS, one plasmid-free strain (TS-1) was selected as an acrystalliferous strain. Strain TS- 1 was confirmed as H-serotype $4 \mathrm{a}: 4 \mathrm{~b}$, the same as the parental strain AF101, by flagellar agglutination.

\section{Phage induction by ethidium bromide}

In plasmid curing experiments, it was observed that cell lysis was induced in strain AF101 during culture in LB broth containing $0.5 \mu \mathrm{M}$ and $5 \mu \mathrm{M}$-ethidium bromide (Fig. 1). Growth was completely inhibited in the presence of $50 \mu \mathrm{M}$-ethidium bromide. Since the cell lysis was considered to be caused by induction with ethidium bromide of a temperate phage or bacteriocin, the cell lysate was examined by electron microscopy. Phage particles (Fig. 2) were detected in the cell lysate and were found to form a single band upon sucrose density-gradient centrifugation of the lysate. Thus, it was concluded that the cell lysis during culture with ethidium bromide occurred upon the induction of one kind of temperate phage, which we termed $\mathbf{J} 7 \mathrm{~W}-1$.

On the other hand, the phage was not induced in the plasmid-free strain TS-1 at a concentration of $1 \mu \mathrm{M}$-ethidium bromide. This result suggests that the induction of $\mathrm{J} 7 \mathrm{~W}-1$ by ethidium bromide in strain AF101 depends on the presence of pAF101.

\section{Host range and properties of $J 7 W-1$}

The host range of $\mathrm{J} 7 \mathrm{~W}-1$ was examined using 26 type strains of $B$. thuringiensis by spotting the phage suspension onto fresh lawns of each strain in soft LB agar. Two type strains (subsp. sotto 


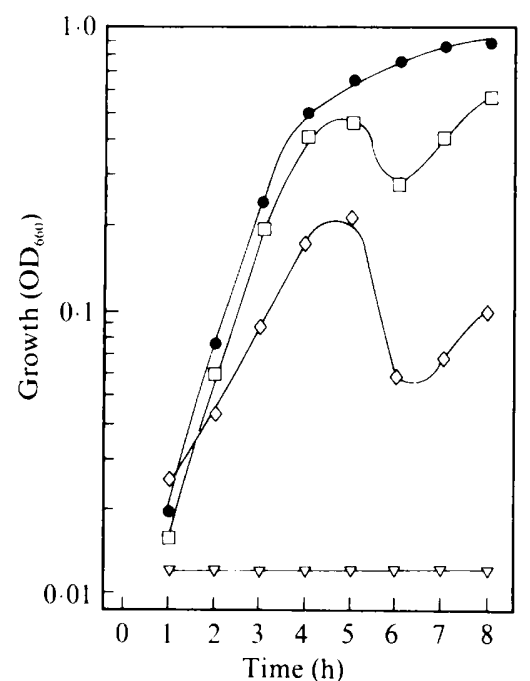

Fig. 1

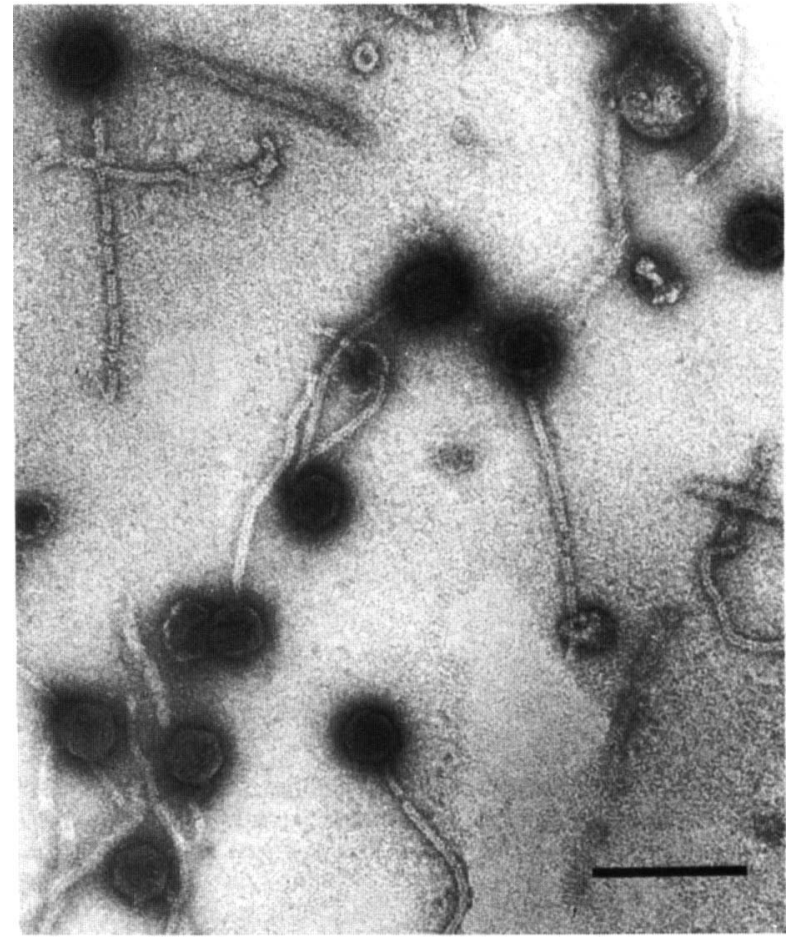

Fig. 2

Fig. 1. Effect of ethidium bromide on the growth of strain AF101. The optical density of cell cultures in LB broth containing $0 \mu \mathrm{M}(\odot), 0 \cdot 5 \mu \mathrm{M}(\square), 5 \mu \mathrm{M}(\diamond)$ and $50 \mu \mathrm{M}(\nabla)$ ethidium bromide was measured at $660 \mathrm{~nm}$.

Fig. 2. Election micrograph of phage $\mathrm{J} 7 \mathrm{~W}-1$ detected in a cell lysate obtained by ethidium bromide treatment of strain AF101. The sample is stained with $1 \%(\mathrm{w} / \mathrm{v})$ uranyl acetate. Bar, $200 \mathrm{~nm}$.

and subsp. israelensis) showed a lytic response to infection by $\mathrm{J} 7 \mathrm{~W}-1$. The sensitivity of these strains to $\mathrm{J} 7 \mathrm{~W}-1$ was reduced if stationary-phase cells were used to prepare the top layers (data not shown). The other 24 type strains tested (subsp. thuringiensis, subsp. finitimus, subsp. alesti, subsp. kurstaki, subsp. dendrolimus, subsp. galleriae, subsp. canadensis, subsp. entomocidus, subsp. subtoxicus, subsp. aizawai, subsp. morrisoni, subsp. ostriniae, subsp. tolworthi, subsp. caucasicus, subsp. darmstadiensis, subsp. toumanoffi, subsp. kyushuensis, subsp. thompsoni, subsp. pakistani, subsp. dakota, subsp. indiana, subsp. tohokuensis, subsp. kumamotoensis, and subsp. tochigiensis) showed no lytic response.

Phage J7W-1 has a head diameter of $65 \mathrm{~nm}$ and a tail length of $290 \mathrm{~nm}$ and is different morphologically from other temperate phages hitherto reported in $B$. thuringiensis (Colasito \& Rogoff, 1969; Iwahana, 1976).

The molecular sizes of fragments produced by digestion of the J7W-1 genome with EcoRI, HindIII, Bgl II and Pst I gave values of $48 \cdot 7,46 \cdot 6,48 \cdot 8$ and $47.9 \mathrm{~kb}$, respectively, for the total size of the phage genome. The molecular size of the J7W-1 genome was estimated to be $48.0 \mathrm{~kb}$, as the mean of these four values.

\section{Location of phage genome}

As the induction of $\mathrm{J} 7 \mathrm{~W}-1$ appeared to be associated wth pAF101, the presence of regions in the chromosome and/or the plasmid homologous to phage DNA was examined by Southern hybridization of cleared lysate against a J7W-1 DNA probe. J7W-1 DNA was able to hybridize to pAF101, but not to the chromosome (Fig. 3). Moreover, comparison of their restriction digests showed that pAF101 contained not only all the J7W-1 DNA fragments but also 


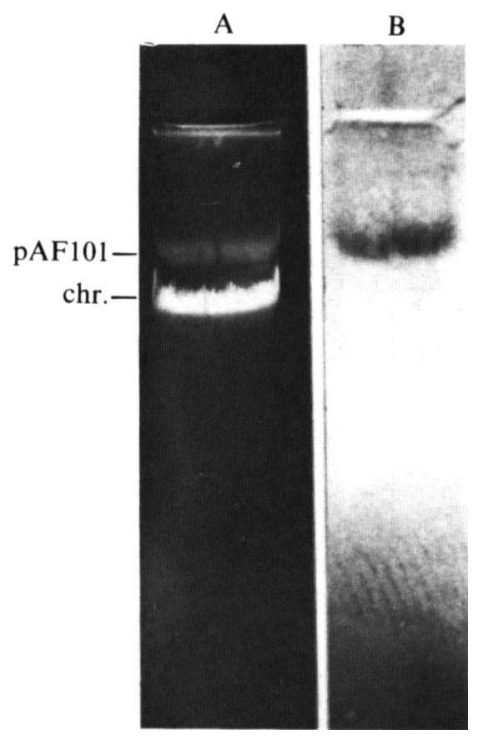

Fig. 3. Location of the J7W-1 genome in strain AF101. DNAs in a cleared lysate of strain AF101 were separated by agarose gel electrophoresis (A). A Southern blot of these DNAs was probed with HindIIIdigested J7W-1 DNA (B). The positions of pAF101 and chromosomal DNA (chr.) are indicated.

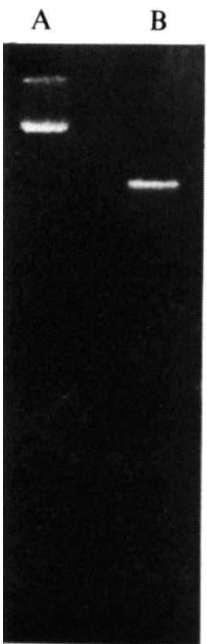

Intact

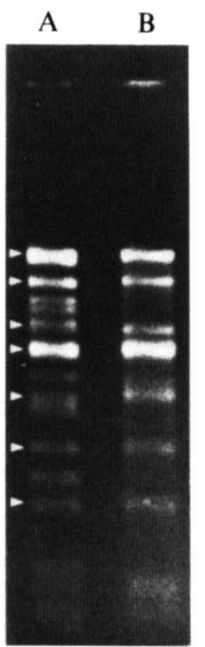

EcoRI

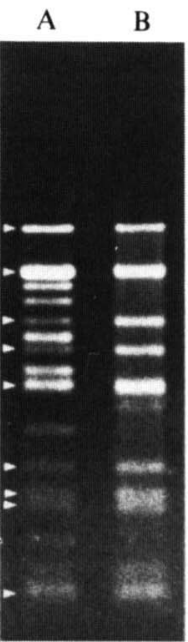

HindIII

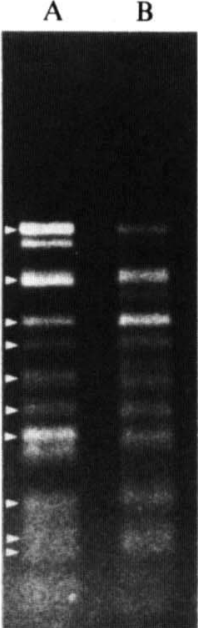

PstI

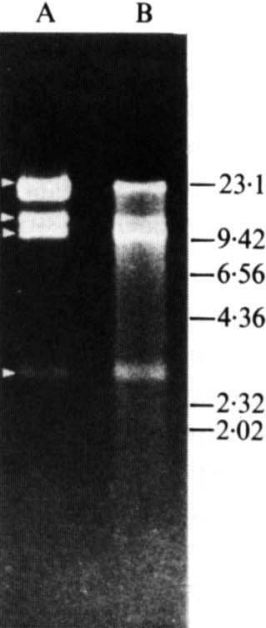

$B g l$ II

Fig. 4. Restriction patterns of pAF101 (A) in comparison with J7W-1 DNA (B). The leftmost two lanes are intact pAF 101 and $J 7 W-1$ DNA. White arrowheads show DNA fragments corresponding to phage DNA. The size markers (in $\mathrm{kb}$ ) on the right indicate the HindIII fragments of phage $\lambda$ DNA.

additional plasmid-specific DNA fragments (Fig. 4). These results strongly suggest that the $\mathrm{J} 7 \mathrm{~W}-1$ genome is integrated into pAF101.

The location of the prophage was also investigated in J7W-1 lysogens of the type strain of B. thuringiensis subsp. israelensis. Lysogenized strains were isolated from surviving colonies on an agar plate after infection by $\mathrm{J} 7 \mathrm{~W}-1$, and these strains were tested to see whether they produced $\mathbf{J} 7 \mathrm{~W}-1$ upon ethidium bromide induction. In all lysogens of subsp. israelensis, a newly acquired plasmid was observed (Fig. 5) and, as expected, it hybridized with J7W-1 genomic DNA (Fig. 6). 


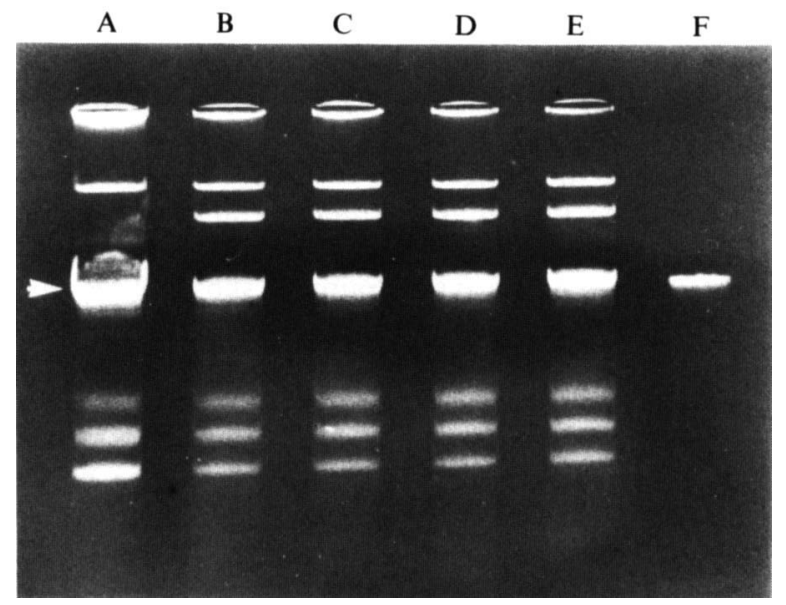

Fig. 5. Agarose gel electrophoresis of DNAs in cleared lysates prepared from the type strain of B. thuringiensis subsp. israelensis (A), lysogens (B-E) and intact J7W-1 DNA (F). The white arrowhead indicates chromosomal DNA.

A

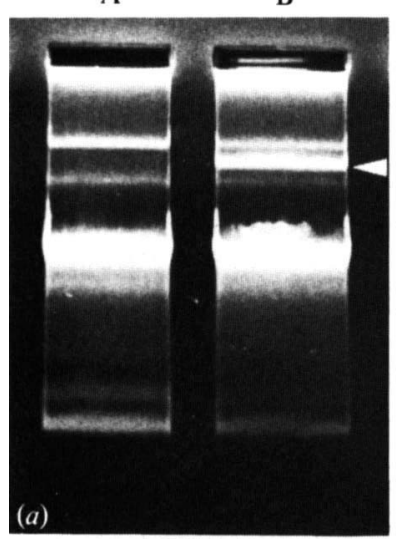

A

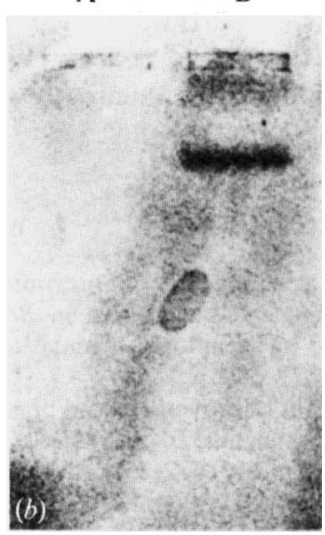

Fig. 6. Location of the $\mathrm{J} 7 \mathrm{~W}-1$ genome in a lysogenic strain of $B$. thuringiensis subsp. israelensis. (a) Agarose gel electrophoresis of DNAs in the cleared lysate prepared from subsp. israelensis (A) and a J7W-1 lysogen (B). (b) Southern blot of the same gel probed wtih HindIII-digested J7W-1 DNA. The white arrowhead indicates the new plasmid homologous to J7W-1 DNA in the lysogenic strain.

\section{DISCUSSION}

We have found that plasmid pAF101 in B. thuringiensis strain AF101 contains a novel temperate phage genome.

It has been reported that the crystal gene is located on plasmids in most subspecies of B. thuringiensis. Strain AF101 appears to possess a single species of plasmid, as is the case for the type strain of subsp. sotto, whose crystal gene has been cloned from a plasmid (Shibano et al., 1985). The present study has shown that a plasmid-cured derivative of strain AF101 lost the ability to produce crystals. This suggests that pAF101 may be closely associated with crystal production (although the possibility that a second, undetected, plasmid is involved cannot be excluded). The location of any crystal gene in pAF101 remains to be resolved.

Ethidium bromide caused phage induction in strain AF101. Phage induction by ethidium bromide has not, to our knowledge, been previously reported. Phage induction in B. thuringiensis, has been reported to occur as a result of UV irradiation and treatment with 
hydrogen peroxide or mitomycin C in strains of subsp. galleriae (Colasito \& Rogoff, 1969), by UV irradiation, mitomycin $C$ and aflatoxin $B_{1}$ treatment in a strain of subsp. tolworthi (Affray \& Boutibonnes, 1985), and by co-cultivation of crystalliferous strain T84-A1 and acrystalliferous strain S-16 both belonging to $\mathrm{H}$-serotype $4 \mathrm{a}: 4 \mathrm{~b}$ (Iwahana, 1976). It appears that treatment with ethidium bromide can induce the phage from the lysogenic strain since it binds to DNA and inhibits DNA synthesis in vivo, in a similar manner to mitomycin C (Bouanchaud et al., 1968). The novel phage, $\mathrm{J} 7 \mathrm{~W}-1$, revealed to be inducible by ethidium bromide in this study, has a relatively narrow host range, i.e. the type strains of subsp. sotto and subsp. israelensis. It is noteworthy that both strains which are susceptible to infection with $\mathrm{J} 7 \mathrm{~W}-1$ possess the same heat-stable somatic antigen (Mike, 1981).

In the lysogenic state, the genomes of most temperate phages are integrated into the host chromosome, while some, such as the prophages of P1 (Ikeda \& Tomizawa, 1968) and N15 (Ravin \& Shulga, 1970), exist as autonomous plasmids in the host cell. The present study demonstrates that the J7W-1 genome is integrated into plasmid pAF101 in strain AF101. This strain appears to have a single plasmid; no other satellite DNA molecules, including free J7W-1 genome, were detected. This indicates that $\mathrm{J} 7 \mathrm{~W}-1$ prophage persists in strain AF101 as an integral part of pAF101; further study on the integration site of J7W-1 in pAF101 is in progress. Furthermore, J7W-1 prophage was present in a plasmid form in $\mathrm{J} 7 \mathrm{~W}-1$ lysogens of subsp. israelensis, since a new plasmid, which hybridized with the $\mathrm{J} 7 \mathrm{~W}-1$ genome, was detected in agarose gel electrophoresis. It is not yet clear whether the prophage is integrated into a preexisting plasmid in these circumstances, or whether it forms an independent plasmid.

According to the evidence presented here, we suggest that phage $\mathrm{J} 7 \mathrm{~W}-1$ could be a novel type of phage which shows a plasmid-dependent prophage state during lysogeny in $B$. thuringiensis.

We would like to thank Dr K. Shimizu for his helpful discussions and advice on this work and $\mathrm{Mr}$ J. S. MacKenzie for reading the manuscript.

\section{REFERENCES}

AfFray, Y. \& Boutibonnes, P. (1985). Discriminated induction of prophage and bacteriocin in Bacillus thuringiensis strains by genotoxic agents. IRCS Medical Science 13, 679-680.

AIZAWA, K. (1971). Strain improvement and preservation of virulence of pathogens. In Microbial Control of Insects and Mites, pp. 655-672. Edited by H. D. Burges \& N. W. Hussey. London \& New York: Academic Press.

Aizawa, K., Fujiyoshi, N., OHba, M. \& Yoshikawa, N. (1975). Selection and utilization of Bacillus thuringiensis strains for microbial control. Proceeding of Ist Intersectional Congress of IAMS, Tokyo, vol. 2, pp. $597-606$.

Aronson, A. I., Beckman, W. \& Dunn, P. (1986). Bacillus thuringiensis and related insect pathogens. Microbiological Reviews 50, 1-24.

Battisti, L., Green, B. D. \& Thorne, C. B. (1985). Mating system for transfer of plasmids among Bacillus anthracis, Bacillus cereus and Bacillus thuringiensis. Journal of Bacteriology 162, 543-550.

Bouanchaud, D. H., ScavizzI, M. R. \& Chabbert, Y. A. (1968). Elimination by ethidium bromide of antibiotic resistance in enterobacteria and staphylococci. Journal of General Microbiology 54, 417-425.

Colasito, D. J. \& Rogoff, M. H. (1969). Characterization of temperate bacteriophages of Bacillus thuringiensis. Journal of General Virology 5, 275-280.

González, J. M., JR \& Carlton, B. C. (1980). Pattern of plasmid DNA in crystalliferous and acrystalliferous strains of Bacillus thuringiensis. Plasmid 3, 92-98.
González, J. M., JR, Dulmage, H. T. \& Carlton, B. C. (1981). Correlation between specific plasmids and delta-endotoxin production in Bacillus thuringiensis. Plasmid 5, 351-365.

González, J. M., JR, Brown, B. J. \& Carlton, B. C. (1983). Transfer of Bacillus thuringiensis plasmids coding for delta-endotoxin among strains of $B$. thuringiensis and $B$. cereus. Proceedings of the National Academy of Sciences of the United States of America 79, 6951-6955.

Ikeda, H. \& Tomizawa, J. (1968). Prophage P1, an extrachromosomal replication unit. Cold Spring Harbor Symposia on Quantitative Biology 33, 791-798.

IWAHANA, H. (1976). Study on the temperate phage of Bacillus thuringiensis. (1) Induction of phage. Science Bulletin of the Faculty of Agriculture, Kyushu University 31, 1-18.

Klier, A., Bourgouin, C. \& Rapoport, G. (1983). Mating between Bacillus subtilis and Bacillus thuringiensis and transfer of cloned crystal genes. Molecular and General Genetics 191, 257-262.

Lereclus, D., Lecadet, M. M., Ribier, J. \& DEDONDER, R. (1982). Molecular relationships among plasmids of Bacillus thuringiensis: converted sequences through 11 crystalliferous strains. Molecular and General Genetics 186, 391-398.

Maniatis, T., Fritsch, E. F. \& SambrooK, J. (1982). Molecular Cloning: a Laboratory Manual, pp. 383385. Cold Spring Harbor, NY: Cold Spring Harbor Laboratory. 
MiKE, A. (1981). Genetic study on the heat-stable somatic antigen of the insecticidal bacterium Bacillus thuringiensis. 39 pp. Master's thesis, Kyushu University.

Ravin, V. K. \& Shulga, M. G. (1970). Evidence for extrachromosomal location of prophage N15. Viro$\log y$ 40, 800-807.

Shibano, Y., Yamagata, A., Nakamura, N., IizuKa,
T., Sugisaki, H. \& Takanami, M. (1985). Nucleotide sequence coding for the insecticidal fragment of the Bacillus thuringiensis crystal protein. Gene 34, 243-251.

TAM, A. \& FitZ-JAMES, P. (1986). Plasmids associated with a phagelike particle and with a satellite inclusion in Bacillus thuringiensis ssp. israelensis. Canadian Journal of Microbiology 32, 382-388. 